\title{
Mechanism of Insulin Resistance in Human Liver Cirrhosis Evidence of a Combined Receptor and Postreceptor Defect
}

\author{
P. Cavallo-Perin, M. Cassader, C. Bozzo, A. Bruno, P. Nuccio, A. M. Dall'Omo, M. Marucci, and G. Pagano \\ Institute of Internal Medicine, University of Turin, Italy; and General Surgery Ward, Ospedale Mauriziano, Turin, Italy
}

\begin{abstract}
Insulin resistance in liver cirrhosis may depend on either reduced sensitivity (receptor defect) and/or reduced response to insulin (postreceptor defect). To clarify the mechanism of such resistance, a $\left.{ }^{3} \mathrm{H}\right]$ glucose infusion $(0.2 \mu \mathrm{Ci} / \mathrm{min})$ was performed for $120 \mathrm{~min}$ before and during a euglycemic clamp at $\sim 100,1,000$, and $10,000 \mu \mathrm{U} / \mathrm{ml}$ steady state plasma insulin concentration in 18 compensated cirrhotics with portal hypertension and impaired glucose tolerance, and 18 healthy volunteers with no family history of diabetes, matched for sex, age, and weight. Mean fasting plasma insulin $(29.2 \pm 3.4$ SEM vs. $14.8 \pm 1.1 \mu \mathrm{U} / \mathrm{ml})$ was significantly higher $(P<0.001)$ in cirrhotics, while fasting plasma glucose was much the same in the two groups.

Glucose use (milligrams per kilogram per minute) was significantly lower in cirrhotics at all three steady state plasma insulin levels: $3.04 \pm 0.34$ vs. $7.72 \pm 0.61(P<0.001)$ at $\sim 100$; $6.05 \pm 1.07$ vs. $11.45 \pm 1.24(P<0.001)$ at $\sim 1,000$; and $11.69 \pm 0.69$ vs. $14.13 \pm 0.74(P<0.05)$ at $\sim 10,000 \mu \mathrm{U} / \mathrm{ml}$. Mean plasma $C$-peptide was significantly higher in cirrhotics both basally and during the steady states $(P<0.001)$; it was completely suppressed at $\sim 10,000 \mu \mathrm{U} / \mathrm{ml}$ in controls and only $57.5 \%$ of the baseline in cirrhotics. Endogenous glucose production (milligrams per kilogram per minute) was much the same in the two groups in the fasting state and almost entirely suppressed in the controls $(0.10 \pm 0.05$ vs. $0.48 \pm 0.11, P<0.001)$ at $\sim 100 \mu \mathrm{U} / \mathrm{ml}$; at $\sim 1,000 \mu \mathrm{U} / \mathrm{ml}$ a residual glucose production, $0.07 \pm 0.05$, was observed in the cirrhotics only. In addition, insulin binding and 3-ortho-methyl-glucose transport were studied in vitro in six cirrhotics and six controls. Insulin binding to circulating monocytes and isolated adipocytes was significantly lower $(P<0.025)$ in cirrhotics in all insulin concentration studies. Glucose transport values on isolated adipocytes were significantly lower in cirrhotics both basally $(P<0.001)$ and at maximal insulin concentration $(P<0.05)$. These results suggest that insulin resistance in human cirrhosis is more dependent on depressed peripheral glucose use than on increased endogenous glucose production, and that a combined receptor and postreceptor defect in insulin action on target cells seems to be present.
\end{abstract}

\section{Introduction}

Carbohydrate intolerance in cirrhosis of the liver has been extensively demonstrated (1-8), ever since Naunyn first coined

Some parts of this study were presented at the 2nd International Symposium on Insulin Receptors, Rome, Italy, September 1983.

Received for publication 26 March 1984 and in revised form 14 January 1985.

J. Clin. Invest.

(c) The American Society for Clinical Investigation, Inc.

0021-9738/85/05/1659/07 \$1.00

Volume 75, May 1985, 1659-1665 the term "hepatogenous diabetes" in 1906 (9). The simultaneous observation of hyperinsulinemia in both the fasting subject and after oral glucose loading $(10,11)$ has pointed to insulin resistance as classically defined by Yalow and Berson (12). Hyperinsulinism may be attributable to liver cell damage resulting in reduced insulin uptake (13) and/or to portosystemic shunt (14-16), while insulin resistance may be the outcome of reduced sensitivity to insulin, whether hepatic (increased gluconeogenesis and glycogenolysis) or peripheral (17), and may occur at the receptor or postreceptor level (18). Hyperglucagonemia $(19,20)$, hypersomatotropinemia $(21,22)$, and high levels of free fatty acids (23-25) have been suggested as potential explanations of this insulin resistance, though further investigation of this question is necessary. Greco et al. (26) have examined insulin resistance mechanisms in cirrhosis through the infusion of glucose-insulin-somatostatin. Their results show that insulin resistance is scarcely influenced by an increase in contrainsular hormones. Work on insulin binding to the target cells (27-29) primarily supports the view that insulin resistance is the consequence of a receptor defect. The present study was run because data showing the extent to which peripheral insulin resistance is due to postreceptor factors is lacking. Three objectives were sought: quantification of insulin resistance in compensated cirrhosis of the liver; assessment of the extent to which insulin resistance is receptoral rather than postreceptoral; and determination of how much of the postreceptor defect is ascribable to changes in the transcellular transport of glucose, which is the first step in the insulinstimulated metabolism of glucose, and is now open to study using relatively manageable techniques (30).

\section{Methods}

Subjects. Fourteen males and four females with cirrhosis of the liver, histologically confirmed by transcutaneous biopsy, were studied (Table I). They were nonobese (Geigy tables) and had no family history of diabetes. Their glucose tolerance tests showed impaired glucose tolerance, according to the National Diabetes Data Group criteria (31).

The only ongoing treatment was $100 \mathrm{mg}$ spironolattone/d. This was stopped $48 \mathrm{~h}$ before each test. All subjects were compensated, with no clinical evidence of edema nor echographic evidence of ascites. Portal hypertension was apparent in the form of splenomegaly and/or endoscopic evidence of esophageal varices, though there had been no hematemesis episodes in the previous month. The controls were 18 healthy volunteers ( 6 with inguinal hernia) matched for sex, age, and weight, with no family history of diabetes and normal glucose tolerance tests (31). None had taken drugs for at least a month. The women were examined in the first two weeks of their menstrual cycle.

18 cirrhotics and 18 controls were randomly subjected to the following: euglycemic-hyperinsulinemic clamp at $\sim 100,1,000$, or $10,000 \mu \mathrm{U} / \mathrm{ml}$ (6 cirrhotics and 6 controls at each level); insulin receptor study on circulating monocytes ( 6 cirrhotics and 6 controls); and study of glucose transport and insulin binding on isolated adipocytes removed a few minutes after nitrogen protoxide induction of anesthesia. Surgery was elective in six cirrhotics (portosystemic anastomosis) and six controls (inguinal hernia) and was performed at least $7 \mathrm{~d}$ after the 
Table I. Details of Cirrhotic Patients

\begin{tabular}{|c|c|c|c|c|c|c|c|c|c|}
\hline Patients & Age & IBW & $\begin{array}{l}\text { Type of } \\
\text { cirrhosis }\end{array}$ & AST & APh & $\begin{array}{l}\text { Total } \\
\text { bilirubin }\end{array}$ & $\begin{array}{l}\text { Serum } \\
\text { albumin }\end{array}$ & Clamp & $\begin{array}{l}\text { Insulin binding and } \\
\text { glucose transport }\end{array}$ \\
\hline & $y r$ & $\%$ & & IU/liter & IU/liter & $m g / d l$ & $m g / d l$ & $\mu U / m l$ & \\
\hline T.T. & 42 & 90 & Postalcoholic & 83 & 241 & 1.7 & 3.4 & 100 & \\
\hline M.A. & 47 & 97 & Postalcoholic & 48 & 127 & 1.0 & 4.2 & 100 & \\
\hline P.L. & 49 & 92 & Cryptogenic & 24 & 93 & 1.2 & 4.3 & 100 & $*$ \\
\hline M.C. & 46 & 86 & Postnecrotic & 48 & 1,262 & 4.2 & 3.7 & 100 & \\
\hline F.A. & 52 & 88 & Cryptogenic & 19 & 71 & 1.4 & 4.1 & 100 & * \\
\hline S.F. & 50 & 92 & Postalcoholic & 31 & 122 & 1.7 & 3.3 & 100 & * \\
\hline L.F. & 41 & 97 & Postalcoholic & 62 & 485 & 1.9 & 3.0 & 1,000 & \\
\hline M.A. & 45 & 95 & Postalcoholic & 59 & 131 & 1.4 & 3.1 & 1,000 & \\
\hline Ma.A. & 52 & 94 & Cryptogenic & 24 & 89 & 1.9 & 4.1 & 1,000 & \\
\hline A.C. & 51 & 93 & Postalcoholic & 39 & 166 & 2.1 & 4.1 & 1,000 & \\
\hline P.M. & 52 & 99 & Postalcoholic & 86 & 138 & 1.9 & 4.2 & 1,000 & \\
\hline Da.P. & 43 & 92 & Cryptogenic & 54 & 92 & 1.7 & 2.5 & 1,000 & $*$ \\
\hline M.G. & 45 & 98 & Cryptogenic & 60 & 103 & 2.7 & 2.4 & 10,000 & \\
\hline U.D. & 48 & 92 & Postalcoholic & 36 & 94 & 1.8 & 2.5 & 10,000 & * \\
\hline B.R. & 47 & 90 & Cryptogenic & 42 & 123 & 1.5 & 3.2 & 10,000 & \\
\hline A.B. & 41 & 90 & Postalcoholic & 53 & 97 & 1.1 & 3.6 & 10,000 & * \\
\hline P.C. & 48 & 92 & Postalcoholic & 60 & 87 & 0.9 & 4.0 & 10,000 & \\
\hline G.P. & 40 & 94 & Postnecrotic & 54 & 199 & 0.9 & 4.1 & 10,000 & \\
\hline
\end{tabular}

IBW, ideal body weight; AST, aspartate serum transferase; APh, alkaline phosphatase.

clamp in the absence of active inflammation or infection. Each subject had followed a balanced diet $(30 \mathrm{kcal} / \mathrm{kg}$ body wt: $50 \%$ carbohydrates, $25 \%$ lipids, and $25 \%$ proteins) for the previous $30 \mathrm{~d}$. Hospitalization before surgery was 1 wk in all cases. During this period, patients were not confined to bed and engaged in moderate physical activity. Informed consent was obtained from all subjects.

Tests. A continual 4-h infusion of D-6- $\left[{ }^{3} \mathrm{H}\right]$ glucose (Amersham, Buckinghamshire, UK) $(12 \mu \mathrm{Ci} / \mathrm{h})$ was carried out at 8 a.m. after a 12-h overnight fast. The clamp was done at three hyperinsulinemic levels by infusing 40,372 , and $1,280 \mathrm{mU} / \mathrm{m}^{2}$ per $\mathrm{min}$ prompt biosynthetic human insulin (Humulin, Eli Lilly Co. Indianapolis, IN). During the first $10 \mathrm{~min}$, the insulin infusion was augmented according to DeFronzo et al. (32). It was started at the 120th min of the $\left[{ }^{3} \mathrm{H}\right]$ glucose infusion and was continued for $120 \mathrm{~min}$. Blood glucose was kept at $\pm 5 \%$ of the fasting value by automatic infusion of a $30 \%$ dextrose solution by means of a biostator (model GCIIS; Ames, Elkhart, IN), using operating mode 7:1 but allowing the operator to intervene manually on the optional glucose channel. The following constants were used: BD (blood glucose levels at which basal dextrose infusion started) $=$ fasting glycemia $+5 \%$; QD (inverse of the static gain for dextrose infusion) $=45$; RD (basal dextrose infusion rate) $=0.8 \mathrm{mg} / \mathrm{kg}$, clamp at $\sim 100 \mu \mathrm{U} / \mathrm{ml}, 2 \mathrm{mg} / \mathrm{kg}$, clamp at $\sim 1,000 \mu \mathrm{U} /$ $\mathrm{ml}$, and $3 \mathrm{mg} / \mathrm{kg}$, clamp at $\sim 10,000 \mu \mathrm{U} / \mathrm{ml}$. The dextrose-infusing tube was replaced with a hemotransfusing apparatus (flow $=5 \mathrm{ml}$ / min; Baxter Laboratories, Morton Grove, IL). Constant infusion of 15 and $30 \mathrm{meq}$ potassium aspartate/h accompanied the $\sim 1,000$ - and $10,000-\mu \mathrm{U} / \mathrm{ml}$ clamps, respectively. All blood samples were taken from the distal arm vein. A heat pad at $60^{\circ} \mathrm{C}$ was applied to the hand to arterialize the venous blood. Gas analysis of blood obtained in this way gave a $\mathrm{PO}_{2}$ of $89 \pm 4 \mathrm{mmHg}$.

Analytical procedure. The glucose levels of blood automatically measured by the biostator were also checked on plasma every $5 \mathrm{~min}$ with a glucose analyzer (model II; Beckman Instruments, Inc., Fullerton, CA). Reproducibility was good (5\% variation). The plasma glucose values were used for the calculation of all indices. Specific plasma radioactivity during the $\left[{ }^{3} \mathrm{H}\right]$ glucose infusion was determined according to Issekutz et al. (33). Insulin was measured by solid-phase antibody radioimmunoassay (Corning kit, Corning Medical, Corning Glass Works, Medfield, MA). Plasma C-peptide under basal conditions and every 30 min during the clamp was measured with a Byk-Mallinkrodt kit (Dietzenbach, Federal Republic of Germany). Insulin binding to circulating monocytes was studied on a $100-\mathrm{ml}$ blood sample with 2 $\mathrm{ml}$ EDTA-Na $\mathrm{Na}_{2}$ from the fasting subjects. Mononucleated leukocytes were isolated by centrifugation on a density gradient according to the methods of Böyum (34). For the competition studies, $40 \times 10^{6} / \mathrm{ml}$ cells were incubated in $100 \mathrm{mmol} /$ liter Hepes (pH 8.0) for $100 \mathrm{~min}$ at $15^{\circ} \mathrm{C}$ with a tracer dose of ${ }^{125} \mathrm{I}$-insulin, and native insulin in increasing concentrations, followed by centrifugation through dibutyl-phtalate $(d$ $=1.04$ ) (35). Radioactivity bound to the cells in the presence of an excess of native insulin $(10,000 \mathrm{ng} / \mathrm{ml})$ was regarded as nonspecific and was subtracted from the total bound at each concentration point to calculate the specific binding value. Cell vitality was determined by exclusion of Trypan blue and it was always $>\mathbf{9 7 \%}$. Monocytes were identified morphologically and cytochemically by the alpha-naphthylacetate esterase method. They formed $20 \pm 3 \%$ of the mononucleated leukocytes. The specific cell-binding fraction was adjusted to a mean concentration of monocytes of $10^{7} / \mathrm{ml}$.

Insulin binding to isolated adipocytes was also examined. Separation by digestion with collagenase and the binding study were done as previously described (36). Only total specific insulin binding at $1 \mathrm{ng} /$ $\mathrm{ml}$ insulin concentration was studied.

The transmembrane transport of glucose was studied according to the methods of Ciaraldi et al. (30). Briefly, cells were preincubated for $60 \mathrm{~min}$ at $37^{\circ} \mathrm{C}$ in the presence of increasing (from 0 to $10 \mathrm{ng} / \mathrm{ml}$ ) concentrations of insulin in a glucose-free medium. The substrate was 3-ortho-methyl-1- ${ }^{14} \mathrm{Clglucose}$ (3-OMG'; New England Nuclear, Boston, MA), which enters the cells but is not metabolized. Incubation with 3-OMG was stopped after $10 \mathrm{~min}$ with a cold $0.3-\mathrm{mM}$ florethine solution, followed by centrifugation, after addition of a layer of silicone oil, to collect the cells for determination of their intracellular radioactivity. The glucose space was corrected by a parallel experiment using L$\left[{ }^{14} \mathrm{C}\right.$ lglucose (Amersham).

Calculations. Basal endogenous glucose production (milligrams per kilogram per minute) was calculated by means of the isotopic dilution

1. Abbreviations used in this paper: IRI, immunoreactive insulin; 3OMG, 3-ortho-methyl-1-[ $\left.{ }^{[4} \mathrm{C}\right]$ glucose; RGP, residual glucose production. 
method, using Steele's formula (37), between the 110th and 120th min of the $\left[{ }^{3} \mathrm{H}\right] g l u c o s e$ infusion. The suppression of this production during the hyperinsulinemic steady state was evaluated and expressed as residual glucose production (RGP) in milligrams per kilogram per minute. Steele's formula was applied to calculate glucose production during the steady state at the specific plasma glucose activity values reached during the clamp. RGP was calculated as the difference between glucose production and De Fronzo et al.'s $M$ value (32) in the same time period, negative values being regarded as $0(17,38)$. Glucose use (milligrams per kilogram per minute) was calculated as $M$ value plus RGP (if any) and used as the index of peripheral insulin sensitivity. All values were expressed as means \pm SEM. $t$ Test was used for the statistical evaluation.

\section{Results}

Plasma glucose levels and insulin and dextrose infusion rates during the clamps are reported in Fig. 1. The mean basal and steady state values are shown in Table II. Basal plasma glucose was much the same in both groups, whereas basal plasma insulin and C-peptide were significantly higher $(P<0.001$ and $<0.05$, respectively) in the cirrhotics, and their molar $C$ peptide/immunoreactive insulin (IRI) ratio was significantly lower at $\sim 100(P<0.001), 1,000(P<0.001)$, and 10,000 $\mu \mathrm{U} / \mathrm{ml}(P<0.05)$. Plasma $C$-peptide, endogenous glucose production, and glucose use in both groups at different insulinemic levels are illustrated in Fig. 2. C-Peptide was significantly higher in the cirrhotics, both basally $(P<0.05)$ and during the steady state clamps $(P<0.001)$. In the controls, it was completely suppressed at $\sim 10,000 \mu \mathrm{U} / \mathrm{ml}$, whereas suppression was only $57.5 \%$ of the baseline in the cirrhotics. Basal endogenous glucose production was $3.28 \pm 0.36 \mathrm{mg} / \mathrm{kg}$ per $\mathrm{min}$ in
Table II. Means \pm SEM of Parameters Measured in Cirrhotics and Controls under Basal Conditions and during Clamps*

\begin{tabular}{|c|c|c|c|}
\hline & Controls & Cirrhotics & \\
\hline \multicolumn{4}{|l|}{ Fasting $(n=18)$} \\
\hline Plasma glucose $(m g / d l)$ & $0.89 \pm 0.01$ & $0.92 \pm 0.01$ & NS \\
\hline Plasma IRI $(\mu U / m l)$ & $14.8 \pm 1.10$ & $29.2 \pm 3.40$ & $P<0.001$ \\
\hline C-peptide/IRI molar ratio & $6.30 \pm 0.37$ & $3.70 \pm 0.34$ & $P<0.001$ \\
\hline \multicolumn{4}{|l|}{$\begin{array}{l}\text { Steady state clamps } \\
\qquad(n=18)\end{array}$} \\
\hline Plasma glucose $(m g / d l)$ & $0.91 \pm 0.03$ & $0.90 \pm 0.02$ & NS \\
\hline $\begin{array}{c}\text { Clamp } \sim 100 \mu \mathrm{U} / \mathrm{ml} \\
(n=6)\end{array}$ & & & \\
\hline Plasma IRI $(\mu U / m l)$ & $85.8 \pm 5.60$ & $86.1 \pm 2.00$ & \\
\hline$M(m g / k g$ per min $)$ & $7.60 \pm 0.62$ & $2.60 \pm 0.30$ & $P<0.001$ \\
\hline \multicolumn{4}{|l|}{$\begin{array}{c}\text { Clamp } \sim 1,000 \mu \mathrm{U} / \mathrm{ml} \\
(n=6)\end{array}$} \\
\hline Plasma IRI $(\mu U / m l)$ & $1,238 \pm 126$ & $1,146 \pm 83$ & \\
\hline$M(m g / k g$ per min $)$ & $11.4 \pm 1.24$ & $5.90 \pm 1.12$ & $P<0.001$ \\
\hline \multicolumn{4}{|l|}{$\begin{aligned} \text { Clamp } & \sim 10,000 \mu \mathrm{U} / \mathrm{ml} \\
(n & =6)\end{aligned}$} \\
\hline $\begin{array}{l}\text { Plasma IRI }(\mu U / m l) \\
M(m g / k g / m i n)\end{array}$ & $\begin{array}{r}10,040 \pm 420 \\
14.1 \pm 0.74\end{array}$ & $\begin{array}{c}9,164 \pm 251 \\
11.6 \pm 0.59\end{array}$ & $\begin{array}{l}\text { NS } \\
P<0.05\end{array}$ \\
\hline
\end{tabular}

* Based on $t$ test.

the cirrhotics, and $3.03 \pm 0.36$ in the controls. During the $\sim 100-\mu \mathrm{U} / \mathrm{ml}$ clamp, it was almost entirely suppressed in the controls (RGP $=0.10 \pm 0.05$ vs. $0.48 \pm 0.11, P<0.001$ ). At $\sim 1,000 \mu \mathrm{U} / \mathrm{ml}$, RGP of $0.07 \pm 0.05$ was observed in the cirrhotics only. Glucose use was significantly lower in the

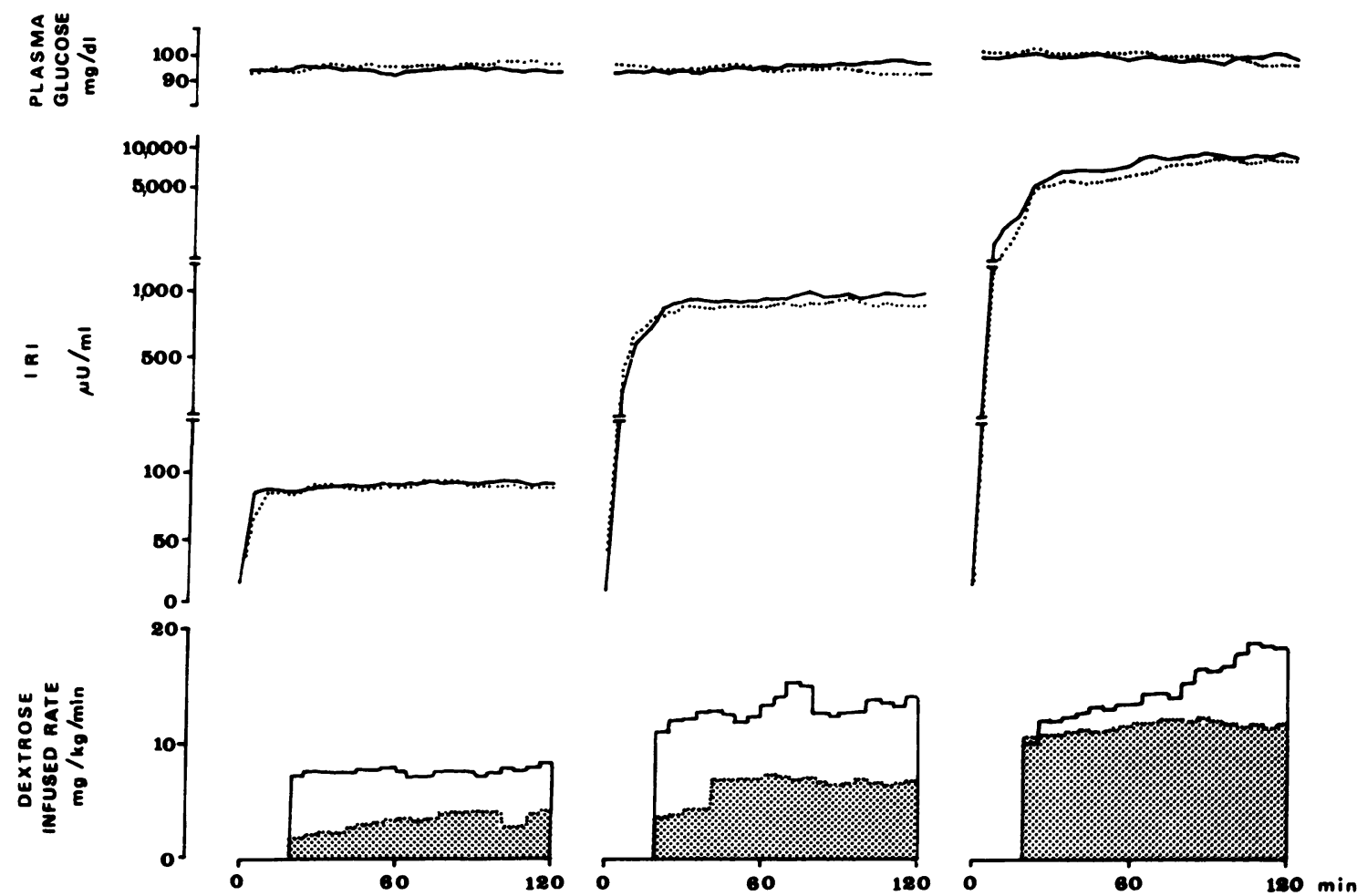

Figure 1. Euglycemic clamp. Mean values of plasma glucose, plasma insulin, and dextrose infusion rate (computed every 5 min), during clamps at $\sim 100,1,000$, and $10,000 \mu \mathrm{U} / \mathrm{ml}$ plasma insulin (IRI) in controls $(-)$ and cirrhotics (-.--). No statistical processing is applicable to the dextrose infusion rate. 

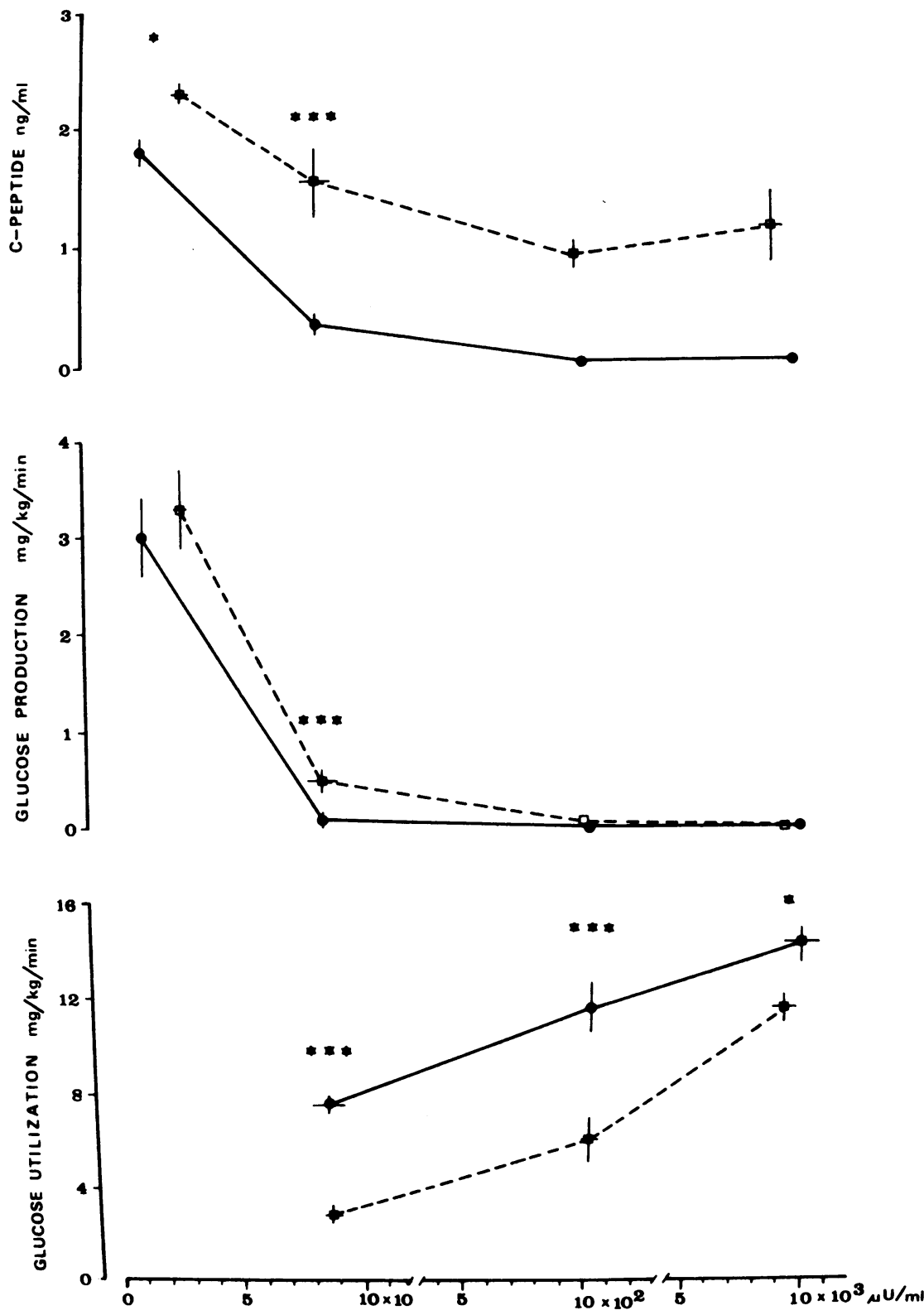

Figure 2. Plasma C-peptide under basal conditions (18 cirrhotics and 18 controls) and at the 120 th min of hyperinsulinemic steady state (6 cirrhotics and 6 controls in each clamp). Glucose production and glucose use at different insulinemic levels. Cirrhotics (ㅁ), controls (๑). Mean \pm SEM. $t$ Test: $(*), P<0.05 ;(* * *)$ $P<0.001$. cirrhotics during the three clamps $(P<0.001$ at $\sim 100$ and $1,000 \mu \mathrm{U} / \mathrm{ml} ; P<0.05$ at $\sim 10,000 \mu \mathrm{U} / \mathrm{ml})$. A rightward shift of the dose-response curve is shown.

Insulin binding to circulating monocytes is presented in the form of competition curve in Fig. 3. Specifically bound radioactivity was significantly lower in the cirrhotics: $2.78 \pm 0.22$ vs. $3.96 \pm 0.34 \%(P<0.025)$.

Insulin binding to isolated adipocytes also showed a significant reduction in the cirrhotics: $2.52 \pm 0.30$ vs. $3.88 \pm 0.46 \%(P$ $<0.025)$. 3-OMG transport values on isolated adipocytes were significantly lower in cirrhotics both in the basal state $(P$ $<0.001)$ and at maximal insulin concentration $(P<0.05)$ (Fig. 4).

\section{Discussion}

Basal plasma insulin levels were significantly higher in the cirrhotics, in keeping with enhanced secretion and/or reduced degradation of the hormone. Since C-peptide and insulin are released from the pancreas in equimolar amounts, and since liver metabolism of C-peptide appears to be negligible (39), plasma C-peptide can be used as the measurement of insulin secretion. Higher basal and during-clamp C-peptide levels in the cirrhotics point to enhanced B cell secretion. Kuhl et al. (40) have shown that C-peptide degradation takes place in the animal liver, though to a lesser extent than insulin $(\sim 50 \%)$. If also observed in man, this finding would be in conflict with the equimolar relationship between C-peptide levels and insulin secretion measurements, especially where liver function is altered. The C-peptide/IRI molar ratio was greatly reduced in the cirrhotics, suggesting that insulin degradation is even more seriously impaired. This interpretation agrees with Johnston et al.'s (10) data of reduced degradation as the cause of hyperinsulinemia in cirrhotics with basal C-peptide levels similar to those of controls.

In the cirrhotics we studied, basal hyperinsulinemia was accompanied by normal plasma glucose, resulting in an insulinresistant state attributable to increased endogenous production 


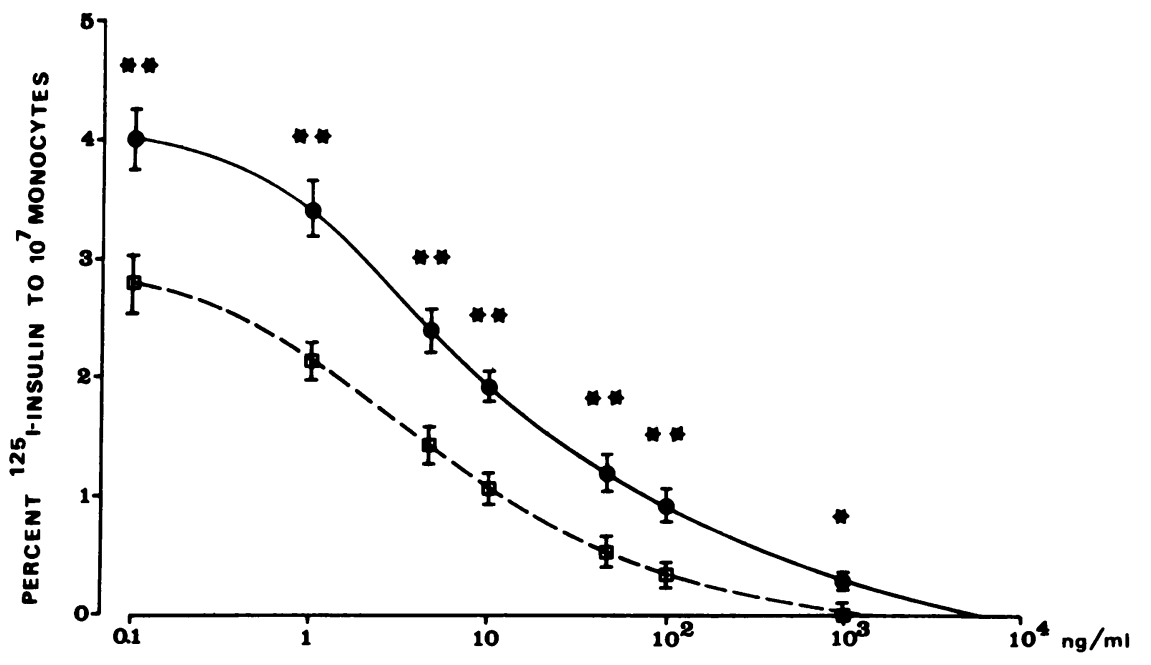

Figure 3. Competition curve on circulating monocytes at $\left[{ }^{125} \mathrm{I}\right]$ monoiodoinsulin in tracer amount $(0.15 \mathrm{ng})$ and increasing concentrations of native insulin from six cirrhotics ( $\square$ ) and six controls $(\bullet)$. Mean \pm SEM. $t$ Test: $(*), P$ $<0.05 ;\left({ }^{* *}\right), P<0.025$

of glucose and/or its reduced peripheral use. The euglycemic clamp is used in vivo to determine whether insulin resistance is the result of reduced sensitivity, reduced responsiveness, or both, according to Kahn (18). The euglycemic clamp has previously been used by us $(41,42)$ and by other investigators $(17,43)$ to study different forms of insulin resistance. In the cirrhotics we studied, a combined receptor and postreceptor defect may be deduced from the rightward shift of the doseresponse curve and the reduced maximum effect at the highest hyperinsulinemic level (Fig. 2). It should be noted that reduced sensitivity to exogenous insulin is less apparent at $\sim 10,000$ $\mu \mathrm{U} / \mathrm{ml}$. It may be that maximum receptor stimulation could have helped to reduce the difference in sensitivity between cirrhotics and controls. A similar lowering of sensitivity has recently been reported in elderly subjects by Rowe et al. (44).

A reduced sensitivity to insulin suppression of glucose production was also measured in the cirrhotics we studied, though the maximum biologic effect was retained (almost complete inhibition at $\sim 10,000 \mu \mathrm{U} / \mathrm{ml}$ ), even though the basal glucose production was not enhanced, suggesting an impairment of insulin modulation of the glucogenetic process. This phenomenon may be partly responsible for resistance, as suggested in a recent editorial by Olefsky (45).

Insulin resistance could also be ascribed to the presence of abnormal insulins in the circulation (hyperproinsulinemia?) (46). In our study, however, this view would be untenable, since reduced peripheral use of glucose was demonstrated through the intravenous infusion of exogenous human insulin.

Of the target cells, monocytes, erythrocytes, and adipocytes have been studied because human liver cells are difficult to study. Most investigators have reported reduced insulin binding on erythrocytes $(26,47)$ and monocytes $(28)$. Harewood et al. (48) alone have found no evidence of defective binding to subcutaneous adipocytes. Our data (Fig. 3) show an $\sim 30 \%$

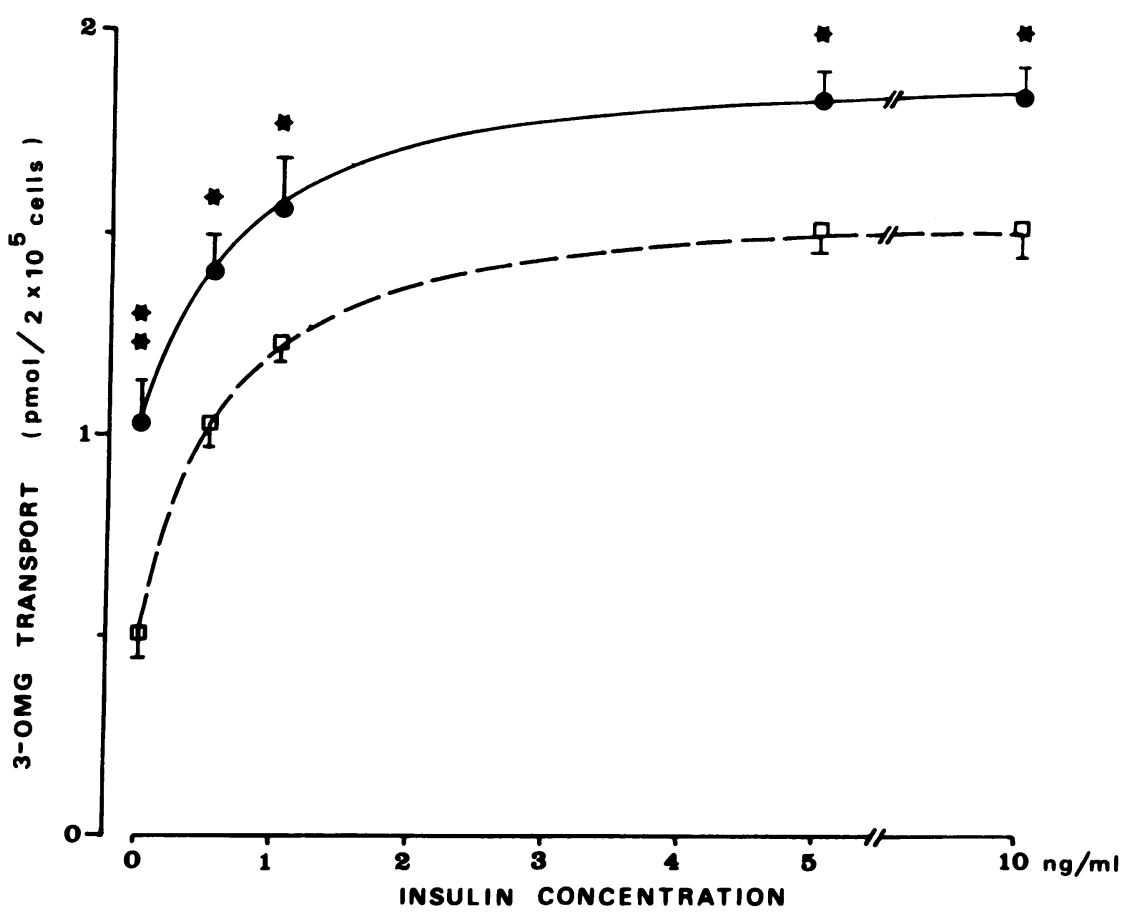

Figure 4. Transmembrane 3-OMG transport curve on adipocytes from six cirrhotics ( $\square$ ) and six controls (๑) at increasing native insulin concentrations. Mean \pm SEM. $t$ Test: $\left(^{*}\right), P<$ $\left.0.05 ;{ }^{* *}\right), P<0.01$. 
reduction in insulin binding to circulating monocytes. Insulin binding on isolated adipocytes, performed at one point only $(1 \mathrm{ng} / \mathrm{ml})$ of insulin concentration, confirmed our results on monocytes. All these data indicate that an insulin receptor impairment is present in liver cirrhosis, perhaps as a consequence of the down-regulation mechanism (49). To evaluate in vitro the postreceptor level, we studied the glucose transport on isolated adipocytes, as recently proposed by others (30).

Evaluation of the transmembrane transport of 3-OMG showed a significant reduction in the basal glucose uptake up to the maximum transport level (Fig. 4). This finding is consistent with the existence of a defect in the initial step of insulin action on cirrhotic adipocytes, even if other steps distal from the receptor may also be involved. This phenomenon should be evaluated also in other target tissues, such as liver and muscle.

In conclusion, we believe that a combined receptor and postreceptor defect in insulin action on target cells is certainly an important cause of insulin resistance in cirrhosis of the liver. Insulin resistance may thus depend in part on the following sequence: decreased insulin degradation by the liver $\rightarrow$ hyperinsulinemia $\rightarrow$ down-regulation $\rightarrow$ insulinbinding decrease. An explanation remains to be found for the postreceptor alteration. Since the glucose transporter is a protein found in two cell pools (membrane and Golgi apparatus) $(50,51)$, it is probably modulated by circulating factors other than insulin, such as glucagon $(19,20)$, growth hormone $(21$, $22)$, intermediary metabolites $(24,25,52)$, etc., whose increased plasma levels are reported in liver cirrhosis. This defect could, moreover, be the primary cause of insulin resistance, contributing to the hyperinsulinism observed in cirrhosis of the liver. The question is open to a final solution because of research primarily designed to define the postreceptor stages and their regulators.

\section{Acknowledgments}

We are indebted to Eli Lilly Co. for their gift of biosynthetic human insulin.

This work was partially supported by grant 83.02141 .04 from the Consiglio Nazionale delle Ricerche and Ricerca Finalizzata Regione Piemonte U7.

\section{References}

1. Riggio, O., M. Merli, C. Cangiano, R. Capocaccia, A. Cascino, A. Lala, F. Leonetti, M. Mauceri, M. Pepe, F. Rossi Fanelli, M. Savioli, G. Tamburrano, and L. Capocaccia. 1982. Glucose intolerance in liver cirrhosis. Metab. Clin. Exp. 31:627-629.

2. Coller, F. A., and F. L. Troost. 1929. Glucose tolerance and hepatic damage. Ann. Surg. 90:781-793.

3. Althausen, T. L., L. Gunther, J. B. Lagen, and W. J. Kerr. 1930. Modification of dextrose tolerance test as index of metabolic activity of the liver. Arch. Intern. Med. 46:482-493.

4. Soskin, S., and I. A. Mirsky. 1935. Influence of progressive toxaemic liver damage upon dextrose tolerance curve. Am. J. Physiol. 112:649-656.

5. Campbell, J. A., and H. J. Tagnon. 1946. Intravenous glucose tolerance test in liver disease. $N$. Engl. J. Med. 234:216-221.

6. Hed, R. 1958. Clinical studies in chronic alcoholism with particular reference to glucose and insulin tolerances. Acta Med. Scand. 162:195-202.

7. Megyesi, C., E. Samols, and V. Marks. 1967. Glucose tolerance and diabetes in chronic liver disease. Lancet. II:1051-1056.
8. Kato, K., S. Kikuchi, and M. Ito. 1973. Clinical investigation on glucose tolerance in liver cirrhosis. Nagoya J. Med. Sci. 35:91-101.

9. Naunyn, B. 1906. Der diabetes mellitus. In Nothnagels Handbuch. Vol. 7.2. A. Holder, editor.

10. Johnston, D. G., K. G. M. M. Alberti, O. K. Faber, C. Binder, and R. Wright. 1977. Hyperinsulinism of hepatic cirrhosis: diminished degradation or hypersecretion? Lancet I:10-12.

11. Johnston, D. G., K. G. M. M. Alberti, R. Wright, S. Sherlock, G. Smith-Laing, A. Stewart, and O. K. Faber. 1978. C-Peptide and insulin in liver disease. Diabetes. 27(Suppl. 1):201-206.

12. Yalow, R. S., and S. A. Berson. 1970. Insulin resistance. In Diabetes Mellitus: Theory and Practice. M. Ellemberg and H. Pifkin, editors. McGraw-Hill Inc., New York. 389-402.

13. Iawasaki, Y., A. Ohkubo, H. Kajinuma, Y. Akanuma, and K. Kosaka. 1978. Degradation and secretion of insulin in hepatic cirrhosis. J. Clin. Endocrinol. Metab. 47:774-779.

14. Alberti, K. G. M. M., D. G. Johnston, and G. Sutton. 1977. Some aspects of carbohydrate metabolism in liver disease. In Diabetes, Obesity, and Hyperlipidemias. G. Crepaldi, P. J. Lefebvre, and K. G. M. M. Alberti, editors. Academic Press, London. 29-39.

15. Smith-Laing, G., S. Sherlock, and O. K. Faber. 1979. Effects of spontaneous portal-systemic shunting on insulin metabolism. Gastroenterology. 76:685-690.

16. Shurberg, J. L., R. H. Resnick, R. S. Koff, E. Rose, R. A. Baum, and J. A. Pallotta. 1977. Serum lipids, insulin and glucagon after porto-caval shunt in cirrhosis. Gastroenterology. 72:301-308.

17. Rizza, A. R., L. J. Mandarino, and J. E. Gerich. 1982. Cortisolinduced insulin resistance in man: impaired suppression of glucose production and stimulation of glucose utilisation due to a postreceptor defect of insulin action. J. Clin. Endocrinol. Metab. 54:131-138.

18. Kahn, C. 1978. Insulin resistance, insulin insensitivity, and insulin unresponsiveness: a necessary distinction. Metab. Clin. Exp. 27:1893-1899.

19. Sherwin, R., M. Fisher, J. Bessoff, N. Snyder, R. Hendler, H. O. Conn, and P. Felig. 1978. Hyperglucagonemia in cirrhosis: altered secretion and sensitivity to glucagon. Gastroenterology. 74: 1224-1228.

20. Sherwin, R., P. Joshi, R. Helder, P. Felig, and H. O. Conn. 1974. Hyperglucagonaemia in Laennec's cirrhosis. N. Engl. J. Med. 290:239-244.

21. Hernandez, A., E. Zorilla, and H. Gershberg. 1969. Decreased insulin production, elevated growth hormone levels and glucose intolerance in liver disease. J. Lab. Clin. Med. 73:25-33.

22. Riley, W. J., and V. J. McCann. 1981. Impaired glucose tolerance and growth hormone in chronic liver disease. Gut. 22:301305.

23. Federspil, G., N. Sicolo, S. Pedrazzoli, M. Zaccaria, E. Zago, and C. Scandellari. 1977. Role of liver in regulating plasma insulin levels and glucose tolerance in man and in animals. In Diabetes, Obesity, and Hyperlipidemias. G. Crepaldi, P. J. Lefebvre, K. G. M. M. Alberti, editors. Academic Press, London. 49-58.

24. Berkowitz, D. 1969. Glucose tolerance, free fatty acid and serum insulin responses in patients with cirrhosis. Am. J. Dig. Dis. 14: 691-697.

25. Gunnlaugsonn, O., and D. Berkowitz. 1977. Individual free fatty acids in patients with liver disease. Am. J. Dig. Dis. 22:10051009.

26. Greco, A. V., A. G. Rebuzzi, L. Altomonte, R. Manna, A. Bertoli, and G. Ghirlanda. 1979. Glucose, insulin and somatostatin infusion for the determination of insulin resistance in liver cirrhosis. Horm. Metab. Res. 11:547-549.

27. Fujita, S., T. Takimoto, M. Kobayashi, Y. Shigeta, and M. Hoshi. 1982. Erythrocyte insulin receptors in patients with chronic liver disease. Horm. Metab. Res. 14:51-52.

28. Greco, A. V., A. Bertoli, G. Ghirlanda, R. Manna, L. Altomonte, 
and A. G. Ribuzzi. 1980. Insulin resistance in liver cirrhosis: decreased insulin binding to circulating monocytes. Horm. Metab. Res. 12:577581.

29. Greco, A. V., A. Bertoli, S. Caputo, L. Altomonte, R. Manna, and G. Ghirlanda. 1983. Decreased insulin binding to the red blood cells in liver cirrhosis. Acta Diabetol. Lat. 20:251-260.

30. Ciaraldi, T. P., O. G. Kolterman, J. A. Siegel, and J. M. Olefsky. 1979. Insulin stimulated glucose transport in human adipocytes. Am. J. Physiol. 236:E621-E625.

31. National Diabetes Data Group. 1979. Classification and diagnosis of diabetes mellitus and other categories of glucose intolerance. Diabetes. 28:1039-1057.

32. De Fronzo, R. A., J. D. Tobin, and R. Andres. 1979. Glucose clamp technique: a method for quantifying insulin secretion and resistance. Am. J. Physiol. 237(3):E214-E222.

33. Issekutz, B. J., M. Allen, and I. Borkow. 1972. Estimation of glucose turnover in the dog with glucose-2-T and glucose-U-14C. Am. J. Physiol. 222:710-712.

34. Böyum, D. 1968. Isolation of mononuclear cells and granulocytes from human blood. Scand. J. Clin. Lab. Invest. 21(Suppl. 97):77-89.

35. Beck-Nielsen, H., and O. Pedersen. 1978. Insulin receptors on monocytes of young healthy persons correlated with glucose tolerance and insulin sensitivity. Diabetologia. 14:159-163.

36. Pagano, G., M. Cassader, and G. Lenti. 1977. Insulin receptors in adipocytes of nondiabetic and diabetic subjects. Preliminary report. Acta Diabetol. Lat. 14:164-169.

37. Steele, R., J. Wall, R. De Bodo, and N. Altszuler. 1956. Measurement of size and turnover rate of body glucose pool by the isotope dilution method. Am. J. Physiol. 187:15-19.

38. Greenfield, M. S., L. Doberne, M. Rosenthal, B. Schultz, A. Widstrom, and G. M. Reaven. 1982. Effect of sulphonylurea treatment on in vivo insulin secretion and action in patients with non-insulindependent diabetes mellitus. Diabetes. 31:307-312.

39. Katz, A., and A. H. Rubenstein. 1973. Metabolism of proinsulin, insulin and C-peptide in the rat. J. Clin. Invest. 52:1113-1120.

40. Kuhl, C., O. K. Faber, P. Hornnes, and S. Lindkaer Jensen. 1978. C-peptide metabolism and the liver. Diabetes. 27:197-200.

41. Pagano, G., P. Cavallo-Perin, M. Cassader, A. Bruno, A.
Ozzello, P. Masciola, A. M. Dall'Omo, and B. Imbimbo. 1983. An in vivo and in vitro study of the mechanism of prednisone-induced insulin resistance in healthy subjects. J. Clin. Invest. 72:1814-1820.

42. Pagano, G., M. Cassader, P. Cavallo-Perin, P. Masciola, and A. Lombardi. 1983. Insulin resistance, insulin binding and glucose transport in human adipocytes in aged people. In Diabetes, Obesity, and Hyperlipidemias. II. G. Crepaldi, P. J. Lefebvre, D. J. Galton, editors. Academic Press, London. 189-194.

43. Kolterman, O. G., R. S. Gray, J. Griffin, P. Burstein, and J. Insel. 1981. Receptor and postreceptor defects contribute to the insulin resistance in non-insulin-dependent diabetes mellitus. J. Clin. Invest. 68:957-969.

44. Rowe, J. W., K. L. Minaker, and J. A. Pallotta. 1983. Characterization of the insulin resistance of aging. J. Clin. Invest. 71 : 1581-1587.

45. Olefsky, J. 1982. Insulin resistance in humans. Gastroenterology. 83:1313-1321.

46. Horwitz, D. L., J. I. Starr, M. E. Mako, W. G. Blackard, and A. M. Rubenstein. 1975. Proinsulin, insulin and C-peptide concentration in human portal and peripheral blood. J. Clin. Invest. 55:1278-1283.

47. Blei, A. T., D. C. Robbins, E. Drobny, G. Baumann, and A. H. Rubenstein. 1982. Insulin resistance and insulin receptors in hepatic cirrhosis. Gastroenterology. 83:1191-1199.

48. Harewood, M. S., J. Proietto, F. Dudley, and F. P. Alford. 1982. Insulin action and cirrhosis: insulin binding and lipogenesis in isolated adipocytes. Metab. Clin. Exp. 31:1241-1246.

49. Teng, C. S., P. W. M. Ho, and R. T. T. Yeung. 1982. Downregulation of insulin receptors in postnecrotic cirrhosis of the liver J. Clin. Endocrinol. Metab. 55:524-530.

50. Czech, N. P. 1980. Insulin action and the regulation of hexose transport. Diabetes. 29:399-409.

51. Cushman, S. W., and L. J. Wardzala. Mechanism of insulin action on glucose transport in the isolated rat adipose cell. Apparent translocation of intracellular transport systems to the plasma membrane. J. Biol. Chem. 255:4758-4762.

52. Johnston, D. G., K. G. M. M. Alberti, C. Binder, O. K. Faber, R. Wright, and H. Orskov. 1982. Hormonal and metabolic changes in hepatic cirrhosis. Horm. Metab. Res. 14:34-39. 